\title{
Cell-Mediated Immune Response of Ragweed-Sensitive Patients to Ragweed Antigen E
}

\author{
IN VITRO LYMPHOCYTE TRANSFORMATION AND \\ ELABORATION OF LYMPHOCYTE MEDIATORS
}

\author{
Ross E. Rockuin, Hobert Pence, Hyman Kaplan, and \\ Richard Evans
}

From the Allergy-Immunology Service, Walter Reed General Hospital, Washington, D. C. 20012

\begin{abstract}
A B S TRACT The in vivo and in vitro responses to ragweed antigen $\mathrm{E}$ were evaluated in 28 untreated atopic patients with ragweed hayfever. The methods employed included direct skin testing, measurement of total serum $\operatorname{IgE}$, measurement of specific $\operatorname{IgE}$ anti-ragweed antibodies, leukocyte histamine release, lymphocyte transformation, and release of lymphocyte mediators (migration inhibitory factor and mitogenic factor). The patients could be divided into sensitive and insensitive groups on the basis of their in vitro reactivity to antigen E. 20 patients in the sensitive group had statistically higher levels of total serum IgE, higher levels of specific IgE anti-ragweed antibodies, and greater leukocyte sensitivity as measured by antigen-induced histamine release than did eight patients in the insensitive group. Lymphocytes from sensitive patients produced greater amounts of migration inhibitory factor and mitogenic factor when challenged by antigen $\mathrm{E}$ than did lymphocytes from insensitive patients. A possible role for the lymphocyte in this allergic disease is discussed. The results of this study indicate that the immune response to ragweed antigen is complex and involves components of both immediate and delayed hypersensitivity.
\end{abstract}

\section{INTRODUCTION}

Ragweed hayfever (seasonal allergic rhinitis) is considered to be a classic example of immediate hypersensi-

This work was presented in part at the 29th Annual Meeting of the American Academy of Allergy, 8-12 February 1973.

Dr. Rocklin's present address is the Robert B. Brigham Hospital, Boston, Mass. 02120.

Received for publication 1 August 1973 and in revised form 22 October 1973. tivity in man. Clinical responses to ragweed antigen have been shown to primarily involve reaginic ( $\operatorname{IgE}$ ) antibody. To what extent components of cellular immunity (delayed hypersensitivity) are involved in this response, however, is not altogether clear. Since it is often difficult to elicit positive delayed hypersensitivity skin tests after the intradermal injection of pollen antigens, some investigators have elected to study in vitro lymphocyte responses to certain pollens as a correlate of in vivo hypersensitivity (1-6). Some of the techniques which measure in vitro lymphocyte activation include the incorporation of $\left[{ }^{3} \mathrm{H}\right]$ thymidine into cellular DNA (7) and the detection of soluble mediators such as migration inhibitory factor (MIF) ${ }^{1}$ and mitogenic (lymphocyte transforming) factor (8).

The purpose of the present study was to evaluate the in vitro lymphocyte response of untreated ragweedsensitive patients to ragweed antigen $\mathrm{E}(\mathrm{RAgE})$ and attempt to correlate these findings with the severity of symptoms, the in vitro antigen-induced leukocyte histamine release (LHR), total serum $\operatorname{IgE}$, and specific $\operatorname{IgE}$ anti-ragweed antibody (IgEAR) levels. Our results showed that the majority of patients have circulating lymphocytes which can respond in vitro to $\mathrm{RAgE}$ by significant $\left[{ }^{3} \mathrm{H}\right]$ thymidine incorporation and mediator production, have sensitive leukocytes as measured by antigen-induced LHR, and have elevated

'Abbreviations used in this paper: B lymphocytes, bone marrow-derived lymphocytes; C culture, unstimulated culture; IgEAR, IgE anti-ragweed antibody; LHR, leukocyte histamine release; MIF, migration inhibitory factor; $\mathrm{RAgE}$, ragweed antigen $\mathrm{E}$; RAST, radioallergosorbent test; $\mathrm{S}$ culture, stimulated culture; SK-SD, streptokinase-streptodornase; $\mathrm{T}$ lymphocytes, thymus-derived lymphocytes; TCA, trichloroacetic acid. 


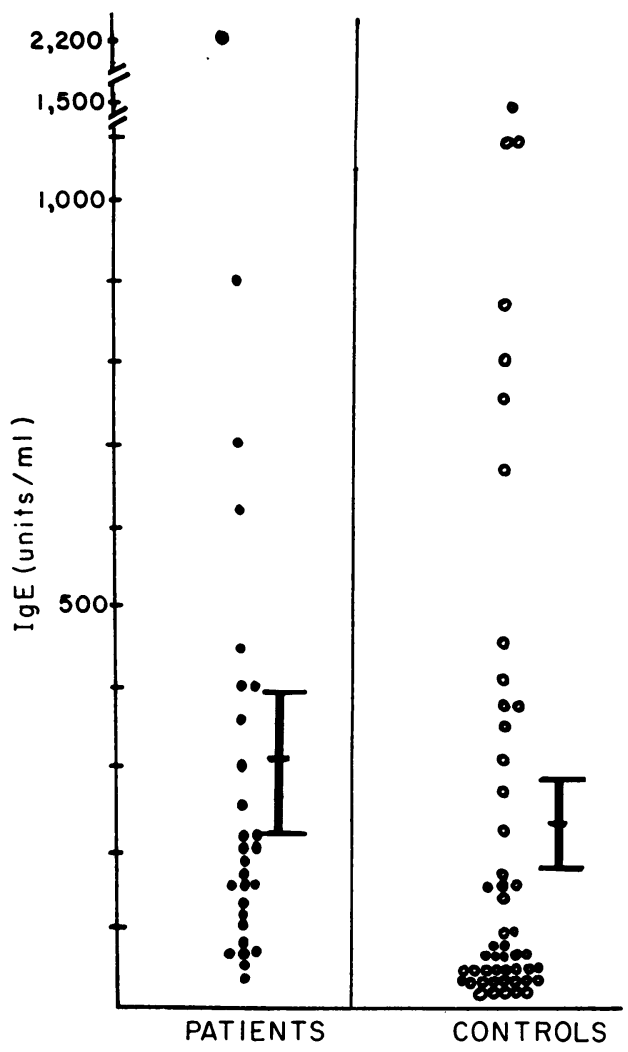

Figure 1 Total (mean \pm SEM) serum IgE levels of patients and controls.

IgEAR levels but normal total serum IgE levels. Of interest was the finding that a small number of patients had diminished lymphocyte mediator production, histamine release, $\operatorname{IgE}$, and $\operatorname{IgEAR}$ levels. One could not distinguish clinically between these two groups.

\section{METHODS}

Patients. 28 atopic patients with symptoms compatible with seasonal allergic rhinitis and no previous history of receiving ragweed immunotherapy were included in this study. The ages ranged from 15 to $64 \mathrm{yr}$ (mean $28.9 \mathrm{yr}$ ) and included 23 males and 5 females. 18 nonatopic subjects served as controls.

Skin tests. At one forearm site $0.05 \mathrm{ml}$ of aqueous ragweed extract (100 protein nitrogen units $/ \mathrm{ml}$ ) alone was injected intradermally. In the opposite forearm $0.05 \mathrm{ml}$ chlorpheniramine maleate $(10 \mathrm{mg} / \mathrm{ml})$ was injected before the subsequent intradermal injection of $0.05 \mathrm{ml}$ ragweed extract at the same site. At a third site chlorpheniramine alone was injected $(0.05 \mathrm{ml})$. The amount of erythema and induration were measured at each site at $15 \mathrm{~min}$ and $48 \mathrm{~h}$. In one subject a punch biopsy specimen was obtained at $48 \mathrm{~h}$ from sites injected with ragweed extract plus chlorpheniramine and chlorpheniramine alone.

Serum IgE levels. Serum samples were obtained from patients at the time of initial evaluation and $\operatorname{IgE}$ levels determined by use of a Phadebas kit purchased from Pharmacia (Uppsala, Sweden). Serum samples for IgE levels were also obtained from 50 subjects in the same age range as the patient population.

Specific IgEAR levels. The radioallergosorbent test (RAST) was used to measure specific IgEAR levels (9). $10 \mathrm{ml}$ of a $20 \%$ whole ragweed extract was conjugated to $500 \mathrm{mg}$ of cyanogen bromide-activated cellulose particles (10). 25-, 50-, and 75- $\mu 1$ samples of sera were added to $0.5-\mathrm{mg}$ aliquots of the antigen-cellulose conjugate and incubated overnight in a horizontal rotator. After washing, $0.05 \mathrm{ml}$ of ${ }^{125}$ I-labeled immunosorbent purified anti-IgE (Fc) was added to each tube. The anti-IgE (kindly supplied by Doctors C. E. Arbesman and J. Wypych) was labeled by use of the chloramine $\mathrm{T}$ method (11) and diluted in a $0.1 \mathrm{M}$ phosphate buffer with $0.5 \mathrm{mg} / \mathrm{ml}$ of goat immunoglobulin G. The $0.05 \mathrm{ml}$ aliquot contained approximately 180,000 counts per minute $(\mathrm{cpm})$. After addition of the ${ }^{125}$ I-labeled anti-IgE, the samples were rotated overnight at room temperature in a horizontal rotator, washed, and counted in a gamma counter. The same serum from a known ragweed-sensitive patient was included in every experiment as a reference standard and the results calculated as a percent of this reference standard.

Antigen-induced leukocyte histamine release. The method of Lichtenstein and Osler (12) was followed as modified by May et al. (13) for small amounts of blood. In brief, leukocytes from $60 \mathrm{ml}$ of venous blood were isolated, washed, and resuspended in a Tris buffer containing $\mathrm{Mg}^{++}$, $\mathrm{Ca}^{++}$, and human serum albumin. Ragweed antigen $\mathrm{E}$ (purchased from Hollister-Stier Laboratories Inc., Yeadon, Pa., and also kindly supplied by Dr. C. Kirkpatrick, NIAID, $\mathrm{NIH})$ was added to the cell suspension in amounts of $10^{-6}-$ $10^{-1} \mu \mathrm{g}$ protein per $\mathrm{ml}$. The released histamine was measured by a fluorometric technique (14). The concentration of $\mathrm{RAgE}$ required to elicit $50 \%$ of the total cellular histamine was used as an indication of the cell sensitivity (15).

Lymphocyte transformation ( $\left[{ }^{3} H\right]$ thy'midine incorporation). $100 \mathrm{ml}$ of heparinized blood was obtained from each subject for the in vitro lymphocyte studies described here and below. A control subject was tested at the same time as the patient. Lymphocytes were isolated by centrifugation on a Ficoll-Hypaque gradient (16), washed, and cultured in medium TC-199 containing 15\% autologous plasma. Cells were cultured alone (control) or in the presence of $\mathrm{RAgE}(50,25$, and $12.5 \mu \mathrm{g}$ protein per $\mathrm{ml})$ and $50 \mathrm{U} / \mathrm{ml}$ of streptokinase-streptodornase (SK-SD) for 6 days at $37^{\circ} \mathrm{C}$ in a $5 \% \mathrm{CO}_{2}-95 \%$ air mixture. $6 \mathrm{~h}$ before terminating the cultures, $1 \mu \mathrm{Ci} /$ tube of $\left[{ }^{3} \mathrm{H}\right]$ thymidine (sp act $5.0 \mathrm{mCi} / \mathrm{mM}$, New England Nuclear, Boston, Mass.) was added. The trichloroacetic acid (TCA)-precipitable protein was isolated by methods previously described (17) and the cpm determined in a scintillation counter. Stimulation ratios were calculated by dividing the mean $\mathrm{cpm}$ (duplicate cultures) of antigen-stimulated cultures by the cpm of unstimulated (control) cultures.

Preparation and assay of lymphocyte mitogenic factor. The method of Maini et al. (5) was followed. 15 million lymphocytes per $1.5 \mathrm{ml}$ were cultured without antigen (control) and in the presence of $75 \mu \mathrm{g}$ protein per $\mathrm{ml}$ of RAgE (stimulated) for $48 \mathrm{~h}$ at $37^{\circ} \mathrm{C}$. At the end of the incubation period the cell-free supernates were obtained and the control supernate reconstituted with antigen (75 $\mu \mathrm{g}$ protein per $\mathrm{ml}$ ). Control and "stimulated" supernates were diluted $1 / 3$ and $1 / 6$ and assayed for mitogenic activity on autologous lymphocytes for 6 days using the method for $\left[{ }^{3} \mathrm{H}\right]$ thymidine incorporation described above. The amount of antigen contained in the supernates was equivalent to $25 \mu \mathrm{g}$ protein per $\mathrm{ml}(1 / 3$ dilution) and $12.5 \mu \mathrm{g}$ protein 
TABLE 1

In Vitro Immune Response to RAgE

\begin{tabular}{|c|c|c|c|c|c|c|c|c|c|c|}
\hline \multirow[b]{2}{*}{ Patient } & \multirow{2}{*}{$\begin{array}{c}\text { Leukocyte } \\
\text { histamine } \\
\text { release* }\end{array}$} & \multirow{2}{*}{$\begin{array}{r}\text { Total } \\
\text { serum } \\
\text { IgE } \ddagger\end{array}$} & \multirow{2}{*}{$\begin{array}{r}\text { RAST } \\
\text { test } \delta\end{array}$} & \multicolumn{3}{|c|}{$\left[{ }^{3} \mathrm{H}\right]$ Thymidine incorporation $\|$} & \multicolumn{2}{|c|}{ MIF⿻ } & \multirow{2}{*}{$\begin{array}{r}\begin{array}{r}\text { Mitogenic } \\
\text { factor** }\end{array} \\
\mathrm{AgE}\end{array}$} & \multirow{2}{*}{$\begin{array}{c}\text { Symptom } \\
\text { scoresłf }\end{array}$} \\
\hline & & & & BKD & $\mathrm{AgE}$ & SKSD & $\mathrm{AgE}$ & SKSD & & \\
\hline 1 (C. R.) & $2.5 \times 10^{-6}$ & 230 & 98 & 160 & 13,837 & 4,992 & 21 & 23 & 43,383 & 12.0 \\
\hline 2 (J. C.) & $3.4 \times 10^{-6}$ & 300 & 193 & 610 & 2,594 & 8,806 & 31 & 35 & 2,808 & 6.0 \\
\hline 3 (C. H.) & $3.2 \times 10^{-5}$ & 460 & 132 & 683 & 2,819 & 8,139 & 31 & 25 & 7,604 & 11.7 \\
\hline 4 (P. D.) & $6.8 \times 10^{-5}$ & 170 & 108 & 571 & 15,342 & 13,826 & -1 & 35 & 100,194 & \\
\hline 5 (P. Un. D.) & $8.8 \times 10^{-5}$ & 70 & 51 & 398 & 8,301 & 5,814 & 34 & 29 & 13,817 & 1.5 \\
\hline 6 (J. Le. J.) & $8.8 \times 10^{-5}$ & 630 & 222 & 808 & 65,804 & 23,252 & 13 & & 96,296 & \\
\hline 7. (E. B.) & $9.6 \times 10^{-5}$ & 120 & 63 & 816 & 3,750 & 2,152 & 52 & & 10,762 & 7.0 \\
\hline 8 (M. K.) & $1.4 \times 10^{-4}$ & 2,220 & 319 & 2,561 & 13,117 & 20,281 & 16 & 20 & 49,555 & \\
\hline 9 (S. G.) & $2.2 \times 10^{-4}$ & 55 & 32 & 2,493 & 12,820 & 24,962 & 32 & 22 & 33,277 & \\
\hline 10 (R. C.) & $2.2 \times 10^{-4}$ & 390 & 133 & 282 & 11,746 & 17,257 & 22 & 40 & 85,247 & \\
\hline 11 (R. W.) & $2.7 \times 10^{-4}$ & 100 & 15 & 353 & 3,473 & 7,769 & 32 & 20 & 12,447 & 4.0 \\
\hline 12 (C. M.) & $3.0 \times 10^{-4}$ & 700 & 215 & 1,809 & 10,889 & 39,140 & 30 & 28 & 13,390 & \\
\hline 13 (M. B.) & $3.5 \times 10^{-4}$ & 30 & 10 & 614 & 19,305 & 21,624 & 25 & 38 & 19,856 & 7.5 \\
\hline 14 (H. L.) & $4.0 \times 10^{-4}$ & 440 & 116 & 2,083 & 45,542 & 8,336 & 44 & 67 & 25,023 & 4.1 \\
\hline 15 (G. Mo.) & $5.4 \times 10^{-4}$ & 60 & 43 & 167 & 1,947 & 1,283 & 11 & 57 & 8,110 & \\
\hline 16 (W. A.) & $6.0 \times 10^{-4}$ & 135 & 23 & 708 & 19,044 & 21,387 & 37 & 51 & 4,423 & \\
\hline 17 (D. W.) & $6.8 \times 10^{-4}$ & 220 & 47 & 717 & 681 & 3,561 & 26 & 55 & 823 & 13.1 \\
\hline 18 (B. Do) & $8.0 \times 10^{-4}$ & 210 & 54 & 681 & 4,600 & 21,367 & -22 & 24 & 17,542 & 22.6 \\
\hline 19 (G. Ma.) & $1.3 \times 10^{-3}$ & 140 & 0 & 210 & 12,999 & 1,562 & 24 & 32 & 171,574 & \\
\hline 20 (M. S.) & $2.0 \times 10^{-3}$ & 900 & 241 & 447 & 5,817 & 22,495 & 21 & 52 & 37,778 & 8.8 \\
\hline 21 (B. Du.) & $1.2 \times 10^{-2}$ & 90 & 0 & 469 & 6,661 & 28,478 & 30 & 27 & 24,077 & \\
\hline 22 (L. G.) & $6.6 \times 10^{-2}$ & 150 & 0 & 1,450 & 24,051 & 25,270 & -1 & 24 & 13,549 & 25.6 \\
\hline 23 (F. S.) & $1.2 \times 10^{-1}$ & 260 & 5 & 163 & 12,228 & 15,004 & 5 & 37 & 25,991 & 8.8 \\
\hline 24 (G. S.) & $5.6 \times 10^{-1}$ & 74 & 0 & 533 & 4,958 & 5,084 & 7 & 38 & 8,293 & 0 \\
\hline 25 (J. K.) & $<50 \%$ & 360 & 0.3 & 506 & 2,401 & 9,680 & 18 & 5 & 10,985 & \\
\hline 26 (M. P.) & $<50 \%$ & 150 & 0 & 317 & 7,416 & 2,824 & 19 & 30 & 12,895 & 11.0 \\
\hline 27 (F. A.) & No release & 70 & 0.6 & 530 & 1,636 & 1,712 & 4 & & 3,183 & \\
\hline 28 (D. K.) & No release & 90 & 1.4 & 427 & 9,087 & 4,300 & 26 & 10 & 11,190 & 4.0 \\
\hline
\end{tabular}

* Antigen concentration to elicit $50 \%$ histamine release ( $\mu \mathrm{g} \mathrm{P}$ per $\mathrm{ml}$ ).

$\ddagger \mathrm{U} / \mathrm{ml}$.

$\S$ Radioallergosorbent test, results expressed as percent of standard serum.

\| Mean cpm, results of $\mathrm{AgE}$ stimulation presented as peak response.

T Percent inhibition of migration.

${ }^{* *} \mathrm{cpm}$, peak response given.

‡ł Average daily symptom scores during the ragweed season from 14 August to 30 September 1972.

per $\mathrm{ml}$ (1/6 dilution). The mitogenic activity of supernates was calculated by subtracting the cpm due to control supernates from those due to the "stimulated" supernate.

Preparation and assay for MIF. The method for MIF production and assay has been described previously (18). 3 million lymphocytes per $\mathrm{ml}$ were cultured in serum-free medium TC-199 without antigen and in the presence of $50 \mu \mathrm{g}$ protein per $\mathrm{ml}$ of RAgE or $50 \mathrm{U} / \mathrm{ml} \mathrm{SK-SD}$. Cellfree supernates were collected for 3 days, pooled, concentrated, and assayed for MIF activity on guinea pig macrophages in capillary tubes (19). The area of migration was drawn at $24 \mathrm{~h}$, determined by planimetry, and the percent migration inhibition calculated from the following formula:

$$
\% \text { Migration inhibition }=100(1.0-X / Y)
$$

where $X$ equals the area of migration in the presence of supernate with antigen (four capillaries) and $Y$ equals the area of migration in the presence of supernate without antigen (four capillaries).

Analysis of results. The data were analyzed for statistical significance using the Student $t$ test for paired means and the coefficient of correlation determined by the Spearman rank method (20).

\section{RESULTS}

Skin tests. All 28 patients included in this study exhibited $10 \mathrm{~mm}$ or greater wheal responses $15 \mathrm{~min}$ after the intradermal injection of ragweed extract alone. Because of the possibility that the immediate skin test response was in part responsible for the failure to develop a subsequent delayed hypersensitivity response at the same site (due to washing away of antigen), another 
TABLE II

$\left[{ }^{3} H\right]$ Thymidine Incorporation

\begin{tabular}{|c|c|c|c|c|c|}
\hline & \multirow[b]{2}{*}{ Background } & \multicolumn{3}{|c|}{ Ragweed antigen $\mathrm{E}$} & \multirow[b]{2}{*}{ SK-SD, 50 U } \\
\hline & & $50 \mu \mathrm{g}$ & $25 \mu \mathrm{g}$ & $12.5 \mu \mathrm{g}$ & \\
\hline \multicolumn{6}{|l|}{ Patients (28) } \\
\hline Mean & $770^{*}$ & 7,492 & 8,553 & 9,993 & 13,262 \\
\hline \pm SEM & \pm 127 & $\pm 1,724$ & $\pm 1,498$ & $\pm 2,435$ & $\pm 1,901$ \\
\hline \multicolumn{6}{|l|}{ Controls (17) } \\
\hline Mean & 512 & 795 & 815 & 724 & 7,273 \\
\hline$\pm \mathrm{SEM}$ & \pm 82 & \pm 144 & \pm 129 & \pm 117 & $\pm 2,176$ \\
\hline Student $t$ test & $0.05>P<0.10$ & $P<0.001$ & $P<0.0001$ & $P<0.001$ & $P<0.01$ \\
\hline
\end{tabular}

Response of patient and control lymphocytes in vitro to RAgE and SK-SI).

* Mean cpm of duplicate cultures.

skin area was pretreated with chlorpheniramine to block the immediate wheal and flare (4). In many patients significant erythema and induration $(5-10 \mathrm{~mm})$ was present at $48 \mathrm{~h}$ in the site pretreated with chlorpheniramine. However, this degree of reactivity was also present at the site of chlorpheniramine injection alone and histologic examination of both sites revealed an inflammatory response which was not considered characteristic of a delayed hypersensitivity reaction since the majority of infiltrating cells were neutrophils and there was no significant perivascular round cell infiltrate. No increase in eosinophils or basophils was noted. It was concluded that cutaneous delayed hypersensitivity could not be demonstrated in any of the patients in response to ragweed antigen.

Serum IgE levels. The serum IgE levels of the 28 patients and 54 controls are shown in Fig. 1 and Table I. The mean $( \pm \mathrm{SEM})$ concentration of IgE for the ragweed patients was $319 \pm 80 \mathrm{U} / \mathrm{ml}$ (range 30-2,200) and that for the controls was $223 \pm 44 \mathrm{U} / \mathrm{ml}$ (range 10 $1,500)$. The difference between the mean serum $\operatorname{IgE}$ levels for patients and controls was not statistically significant.

Specific IgEAR (RAST). The RAST antibody concentrations ranged from $0-319 \%$ of the standard as shown in Table I. Nine patients had a serum RAST level of less than 10. Leukocytes from $8 / 9$ of these patients were also considered insensitive when evaluated by antigen-induced LHR (21). These lower levels of the RAST test are similar to those obtained from 15 normal nonatopic subjects.

Leukocyte histamine release. The individual assay results of antigen-induced histamine release to varying doses of $\mathrm{AgE}$ are listed in Table I. Leukocytes from $24 / 28$ patients released $50 \%$ cellular histamine in response to at least one dose of AgE. Leukocytes from four patients (J. K., M. P., F. A., and D. K.) did not release $50 \%$ of their histamine and were considered insensitive to ragweed $\mathrm{AgE}$. In addition, leukocytes from four other patients (B. Du., L. G., F. S., and G. S.) were also considered insensitive to $\mathrm{AgE}$ because of the high concentration of antigen required to release this amount of histamine (21).

Lymphocyte transformation. The amounts of $\left[{ }^{3} \mathrm{H}\right]$ thymidine incorporated into cellular DNA by lymphocytes from patients and controls in response to several doses of RAgE and SK-SD are illustrated in Table II and Fig. 2. The mean ( \pm SEM) cpm obtained from unstimulated patient cultures (Table II) was higher $(770 \pm 127)$ compared to normal controls (512 \pm 82$)$, but this difference was not statistically significant $(0.05$ $>P<0.1)$. Significant incorporation of $\left[{ }^{3} \mathrm{H}\right]$ thymidine by lymphocytes from the patient group (compared with

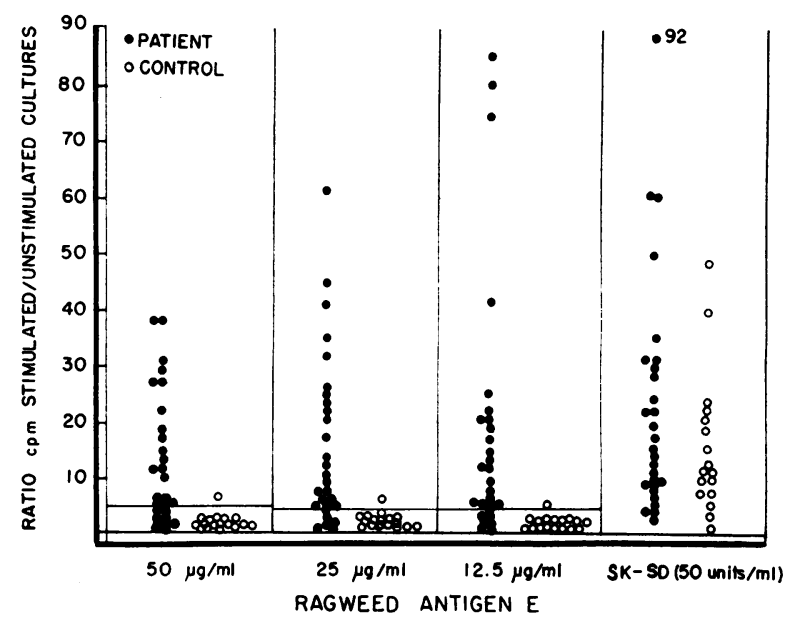

FIGURE 2 Tritiated thymidine uptake showing stimulation ratios of patients and controls responding to $\mathrm{RAgE}$ and SK-SD. 
TABLE III

Mitogenic Factor Production

\begin{tabular}{|c|c|c|c|c|c|c|}
\hline & \multicolumn{3}{|c|}{ 1:3 Dilution $(25 \mu \mathrm{g})$} & \multicolumn{3}{|c|}{ 1:6 Dilution $(12.5 \mu \mathrm{g})$} \\
\hline & Stim. (S) & Controls (C) & $s-c$ & Stim. (S) & Controls (C) & $s-c$ \\
\hline \multicolumn{7}{|l|}{ Patients (28) } \\
\hline Mean & $39,031^{*}$ & 14,191 & 24,840 & 42,991 & 17,175 & 25,811 \\
\hline$\pm \mathrm{SEM}$ & $\pm 6,939$ & $\pm 2,702$ & $\pm 5,750$ & $\pm 9,158$ & $\pm 3,238$ & $\pm 7,058$ \\
\hline \multicolumn{7}{|l|}{ Controls (17) } \\
\hline Mean & 5,160 & 4,669 & 491 & 5,848 & 5,356 & 435 \\
\hline$\pm \mathrm{SEM}$ & $\pm 1,298$ & $\pm 1,171$ & \pm 654 & $\pm 1,494$ & $\pm 1,520$ & \pm 392 \\
\hline Student $t$ test & & & $P<0.001$ & & & $P<0.001$ \\
\hline
\end{tabular}

Supernate from RAgE-stimulated (S) and control (C) patient and control lymphocytes assayed for mitogenic activity on autologous lymphocytes.

* Mean cpm of duplicate cultures.

controls) was observed in response to 50,25 , and 12.5 $\mu \mathrm{g}$ protein per $\mathrm{ml} \mathrm{AgE}$. It is of note that the maximum response to $\mathrm{RAgE}$ occurred with the latter dose of antigen (Table II). The higher doses of RAgE may have been somewhat toxic to cells although there was no significant difference between the mean levels for each dose. Furthermore, the response by patients' lymphocytes to SK-SD was also significantly greater than the control response. However, if the mean cpm of stimulated (S) and unstimulated (C) cultures are converted

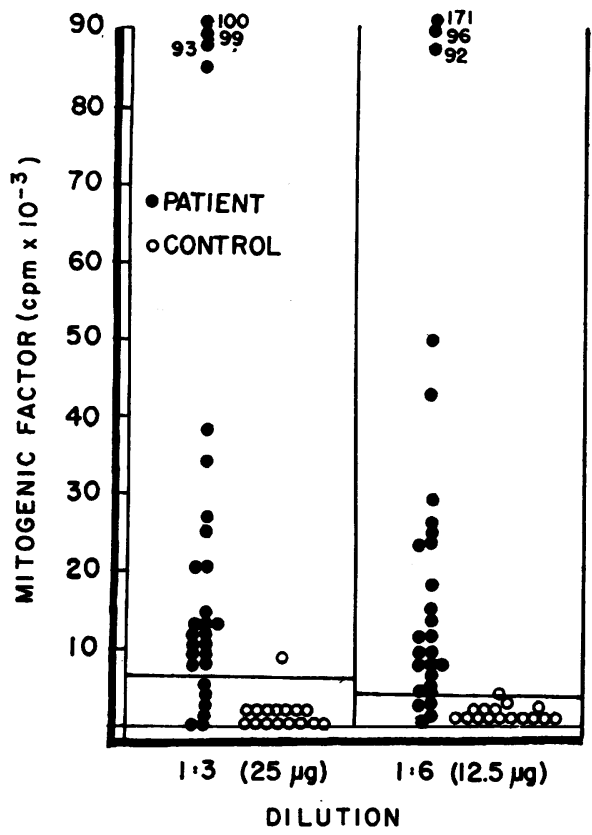

FIGURE 3 Mitogenic factor activity of supernates (diluted $1 / 3$ and 1/6) obtained from patient and control lymphocytes stimulated by $75 \mu \mathrm{g}$ protein per $\mathrm{ml}$ of RAgE. to stimulation ratios ( $\mathrm{S} / \mathrm{C})$, then only the $\mathrm{AgE}$ response differs significantly between patients and controls (Fig. 2). Lymphocytes from 22/28 patients were stimulated to incorporate increased amounts of $\left[{ }^{8} \mathrm{H}\right]$ thymidine by at least one concentration of $\mathrm{AgE}$, whereas lymphocytes from only $1 / 18$ controls responded similarly. The response to SK-SD was comparable in both groups.

Mitogenic factor production. Lymphocytes from patients and controls were evaluated for their ability to elaborate a mitogenic material which nonspecifically stimulates other lymphocytes to incorporate increased amounts of $\left[{ }^{3} \mathrm{H}\right]$ thymidine. Cell-free supernates from $\mathrm{AgE}$-stimulated and control cultures were diluted $1 / 3$ and $1 / 6$ and assayed on autologous lymphocytes for increased $\left[{ }^{3} \mathrm{H}\right]$ thymidine incorporation 6 days later. Since both control and stimulated supernates contain the same amount of antigen, any increase in $\left[{ }^{3} \mathrm{H}\right]$ thymidine incorporation in cultures containing supernates from stimulated lymphocytes was attributed to mitogenic factor being present in the preparation. The results of assays comparing mitogenic factor production by lymphocytes from patients and controls are summarized in $\mathrm{Ta}$ ble III. It may be seen that the net (cpm-stimulated minus cpm control) mitogenic activity of supernates obtained from antigen-stimulated patients' lymphocytes (diluted $1 / 3$ and $1 / 6$ ) was statistically greater than that obtained from control lymphocytes $(P<0.001)$. The results of individual assays are shown in Fig. 3. Lymphocytes from 24/28 patients were seen to produce significant quantities of mitogenic factor compared to lymphocytes from only $1 / 17$ controls.

MIF production. Supernates obtained from control cultures and lymphocytes stimulated by $\mathrm{AgE}$ and SK-SD were assayed for their inhibitory activity on the migration of guinea pig macrophages in capillary tubes. MIF production by lymphocytes from patients and controls 


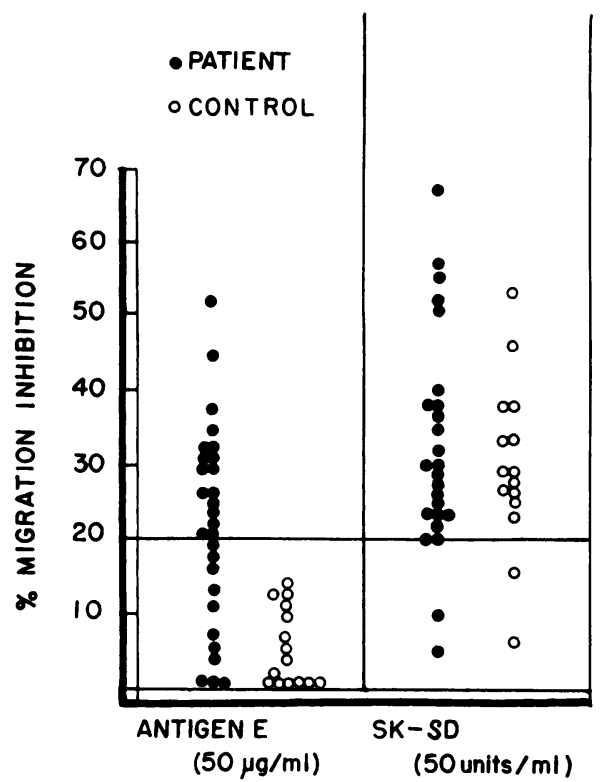

FIgURE 4 Macrophage MIF activity of supernates obtained from patient and control lymphocytes stimulated by RAgE and SK-SD.

are summarized in Table IV. The mean percent migration inhibition for supernates obtained from patients' lymphocytes stimulated by $50 \mu \mathrm{g} / \mathrm{ml}$ of $\mathrm{RAgE}$ contained significantly greater inhibitory activity $(21 \% \pm 2.9)$ than did supernates from control lymphocytes $(0.4 \% \pm 2.9)$. Both groups produced similar amounts of MIF in response to SK-SD. The results of individual assays are depicted in Fig. 4. Using previously established criterion for the production of MIF (18), lymphocytes from $17 / 28$ patients were shown to have produced significant quantities of $\mathrm{MIF}$ in response to $\mathrm{AgE}$. Lymphocytes

TABLE IV

Macrophage MIF Production

\begin{tabular}{ccc}
\hline & \multicolumn{2}{c}{$\%$ migration inhibition } \\
\cline { 2 - 3 } & ANTIGEN E & SK-SD \\
\hline Patients (28) & 21 & 33 \\
Mean & \pm 2.9 & \pm 2.9 \\
\pm SEM & & \\
Controls (17) & 0.4 & 30 \\
Mean & \pm 2.9 & \pm 2.8 \\
\pm SEM & $P<0.001$ & $P=$ NS
\end{tabular}

Supernate from RAgE-stimulated patient and control lymphocytes were assayed for inhibitory activity on guinea pig macrophages in capillary tubes. from none of the controls produced significant quantities of MIF.

Correlation of in vitro assays. Data from the in vitro assays were ranked and the coefficient of correlation determined. Leukocyte histamine release, total serum $\operatorname{IgE}$, and specific IgEAR (RAST) levels, lymphocyte transformation, MIF, and mitogenic factor production were compared to each other. The only significant correlations found were between histamine release (leukocyte sensitivity) and specific IgEAR levels ( $r s=0.771$; $P<0.001$ ) and amounts of mitogenic factor produced and degrees of lymphocyte transformation ( $r s=0.665$; $P<0.001)$.

\section{DISCUSSION}

Previous studies involving patients with allergic rhinitis have utilized in vitro methods which measure one or more parameters of humoral or cellular hypersensitivity. The present study is unique in that these parameters were evaluated in the same patient. All of the patients were selected on the basis of their sensitivity $(3-4+$ immediate skin reactions) to whole ragweed extract. However, the patients did not respond uniformly in vitro to the major antigenic determinant (RAgE) in this preparation. Determination of cell sensitivity defined a sensitive group of 20 patients and a relatively insensitive group of 8 patients. Sensitivity was determined by the amount of RAgE necessary to release $50 \%$ of total cellular histamine using the criteria of Lichtenstein et al. (21). The sensitive group had certain features in common with regard to their response to $\mathrm{RAgE}$. For example, Table $\mathrm{V}$ shows that patients in the sensitive group had statistically higher $\mathrm{IgE}$ levels in general compared with patients in the insensitive group, and they also had much higher levels of specific IgEAR (RAST levels). Furthermore, lymphocytes from the sensitive group elaborated greater amounts of MIF and mitogenic factor in response to $\mathrm{RAgE}$ than did lymphocytes from the insensitive group. However, the MIF response to an unrelated antigen (SK-SD) in each group was not different, indicating that both were capable of responding to an antigen to which $95 \%$ of the normal population will react.

Of interest was the observation that lymphocyte transformation could not distinguish between the patients on the basis of their sensitivity to RAgE. In addition, symptoms scores computed by the method of Lichtenstein et al. (21) did not reveal any differences in the severity of the symptoms between the sensitive and insensitive patients.

These findings indicate that while the majority of patients with ragweed hayfever make a broad immune response to the major antigenic determinant ( $\mathrm{RAgE})$ in ragweed extract, a small number do not. It is possible 
TABLE V

Immunologic Response to AgE

\begin{tabular}{lccc}
\hline & \multicolumn{2}{c}{ Histamine release } & \\
\cline { 2 - 3 } & Sensitive (20) & Insensitive (8) & Student $t$ test \\
\hline Total serum IgE, $U / m l$ & $367.7 \pm 102.4$ & $164.0 \pm 41.7$ & $P<0.01$ \\
Anti-ragweed antibodies & & & \\
$\quad$ (\% STD) & $105.8 \pm 20.0$ & $0.91 \pm 0.6$ & $P<0.001$ \\
MIF (\% inhibition) & & & \\
AgE & $24.2 \% \pm 3.4$ & $11.1 \% \pm 3.8$ & $P<0.025$ \\
SK-SD & $35.8 \% \pm 3.3$ & $24.0 \% \pm 5.6$ & $P=\mathrm{NS}$ \\
Mitogenic factor, cpm & $37,129 \pm 9,317$ & $12,401 \pm 2,676$ & $P<0.001$ \\
Lymphocyte transformation & & & \\
Background & $840 \pm 160$ & $560 \pm 159$ & $P=\mathrm{NS}$ \\
AgE & $13,337+3,368$ & $8,825 \pm 2,952$ & $P=\mathrm{NS}$ \\
S/C & 15.9 & 15.8 & \\
SK-SD & $14,642 \pm 2,255$ & $9,125 \pm 3,255$ & $P=\mathrm{NS}$ \\
S/C & 17.4 & 16.3 & \\
Symptom index, score/day & 9.0 & 10.0 & $P=\mathrm{NS}$ \\
\hline
\end{tabular}

that while leukocytes from the insensitive patients do not respond in vitro to $\mathrm{RAgE}$, their cells might react to another antigenic determinant in the ragweed preparation in vivo. Furthermore, these ragweed-insensitive patients might experience symptoms because of sensitivity to other extrinsic allergens and their skin reaction to ragweed extract is not clinically related to their problem. In this regard it is of interest that, in addition to ragweed, $6 / 8$ insensitive patients had positive immediate skin tests to one or more allergens (which is similar to the incidence of positive skin tests in the ragweedsensitive group). Lichtenstein et al. (21) have also observed a group of patients who were diagnosed as having ragweed hayfever but whose leukocytes respond poorly in vitro to ragweed antigen and have suggested that these patients may be sensitive to other antigens which may provoke their symptoms.

The present study clearly demonstrates that patients with a disease classically associated with immediate-type hypersensitivity (ragweed hayfever) have circulating lymphocytes which recognize and respond to the extrinsic allergen (ragweed antigen). This response was detected in vitro by employing methods which have been shown to correlate with in vivo delayed hypersensitivity. These include antigen-induced lymphocyte transformation and measuring the elaboration of lymphocyte mediators (MIF and mitogenic factor). Other investigators have previously shown that lymphocytes from atopic patients with summer or fall hayfever transformed and/ or incorporated increased amounts of $\left[{ }^{3} \mathrm{H}\right]$ thymidine in vitro (1-5) and produced mediators (4-6) in response to grass or ragweed pollen antigens. We found that lymphocytes from $22 / 28$ patients with ragweed hayfever incorporated increased amounts of $\left[{ }^{3} \mathrm{H}\right]$ thymidine in response to $\mathrm{RAgE}$. Moreover, circulating lymphocytes from 17/28 patients produce MIF when challenged by this antigen. The production of lymphocyte mediators was more closely linked to the immune response to $\mathrm{RAgE}$ in general, i.e., those patients whose lymphocytes produced mediators also had significant immediate hypersensitivity responses (LHR and specific IgEAR). Maini et al. (5) demonstrated that lymphocytes from the majority of their patients with summer hayfever produced a mitogenic factor for lymphocytes in response to grass antigens but only a few $(6 / 20)$ produced MIF. Similarly, Brostoff and Roitt (4), and Massie and Wutanasupta (6) found that lymphocytes from $1 / 4$ to $1 / 3$ of their patients produced MIF to grass or ragweed antigens and in one study (5) the production of MIF primarily occurred in patients who had received immunotherapy with grass extracts.

None of our patients developed positive delayed hypersensitivity skin tests after the intradermal injection of ragweed extract even when antihistamines were administered to block the immediate reaction. This finding contrasts with the reports of others $(4-6,22)$. The explanation for this is not known, but other workers have also experienced similar difficulties in attempting to demonstrate delayed hypersensitivity skin tests (23). It should be pointed out that the concentration of antihistamine used in the present study $(0.05 \mathrm{ml})$ was larger than that employed in the other studies $(0.02$ 
$\mathrm{ml})$; this resulted in nonspecific inflammatory changes which may have obscured our findings and could explain the contrasting results.

Total serum IgE levels in our patients (mean $319 \pm 80$ $\mathrm{U} / \mathrm{ml}$ ) did not differ significantly from the control population (mean $223 \pm 44 \mathrm{U} / \mathrm{ml}$ ). This would appear to be at variance with the findings of other investigators (2426) who have shown that patients with allergic rhinitis have higher total serum IgE levels than the normal population. The main reason for this is the difference in $\operatorname{IgE}$ levels found in the sensitive and insensitive groups ( $\mathrm{Ta}$ ble $\mathrm{V}$ ). The mean $\mathrm{IgE}$ levels for the sensitive group was $378 \pm 102.4 \mathrm{U} / \mathrm{ml}$ and that for the insensitive group $167 \pm 41.7 \mathrm{U} / \mathrm{ml}$. If a comparison is made with just the $\mathrm{IgE}$ levels from the sensitive group with those of the normal population then a significant $(P=0.05)$ difference is noted.

Several significant correlations became apparent when comparisons of the six in vitro immunologic responses were made. Spearman rank correlation of the data revealed that leukocyte sensitivity (histamine release) and levels of specific IgEAR (RAST) closely correlated $(r s=0.771 ; P<0.001)$. In addition, a significant correlation $(r s=0.665 ; P<0.001)$ was noted between the amount of mitogenic factor released by lymphocytes and the degree of lymphocyte stimulation $\left(\left[{ }^{3} \mathrm{H}\right]\right.$ thymidine incorporation). It is of interest that of the two lymphocyte mediators measured, only mitogenic factor closely correlated with lymphocyte transformation. It should be noted, however, that this latter finding is not unexpected since the assay for mitogenic factor employs the degree of lymphocyte transformation as an end point and therefore a certain bias is introduced into the system. Similar correlations between histamine release and RAST levels (27) or of mitogenic factor and lymphocyte transformation have been reported (5).

Since this and previous studies have shown that patients with diseases associated with immediate hypersensitivity have circulating lymphocytes that can recognize and react to the extrinsic allergen in vitro, the question generated by these observations concerns the role of the lymphocyte in allergic diseases. It is well known that thymus-derived ( $\mathrm{T}$ ) lymphocytes mediate such reactions as the cutaneous expression of delayed hypersensitivity, resistance to certain infections, homograft rejection, and some autoimmune diseases (28). It has also been shown that $T$ lymphocytes cooperate with bone marrow-derived (B) lymphocytes (plasma cell precursors) in antibody production to certain antigens (29). Therefore, several possibilities are suggested for the role of $\mathrm{T}$ lymphocytes in the expression of allergic diseases. For example, in the present study it was shown that lymphocytes from ragweed-sensitive patients produced mediators (MIF and mitogenic factor) and transformed in response to $\mathrm{RAgE}$. These responses are generally thought to reflect a state of in vivo delayed hypersensitivity in the host (8). Although our patients did not exhibit positive delayed skin tests after challenge by $\mathrm{RAgE}$, it is still possible that they possess in vivo delayed hypersensitivity, but for reasons which are not clear at present it was not expressed as cutaneous reactivity. It is of note that Slavin and coworkers (30) also could not demonstrate the presence of delayed hypersensitivity skin tests in his patients (treated with emulsified ragweed extract) but through cell transfer studies showed that nonallergic recipients developed positive delayed skin tests indicating that the allergic donors possessed sensitive leukocytes.

Several possibilities may be suggested to explain the inability of atopic patients to express cutaneous delayed hypersensitivity to an allergen which elicits a lymphocyte response. First, the immediate skin reaction may prevent the development of a subsequent delayed skin reaction by "washing" antigen away from the reaction site. We tried to overcome this problem with the use of antihistamines but this approach was not successful. Another possibility is the presence of a serum factor in atopic patients which blocks in vivo cutaneous delayed hypersensitivity. The effect of such an inhibitor might not be detected in some of the in vitro assays because no serum or normal human serum is routinely used. Alternatively, there may be a partial defect in the T-cell response to ragweed antigen in atopic patients with regard to mediator production. Although MIF was elaborated, other mediators (such as chemotactic factor and lymphotoxin), which may also be necessary for the development of delayed hypersensitivity skin reactions, might not have been produced. The presence of apparent normal lymphocyte function (MIF production and $\left[{ }^{3} \mathrm{H}\right]-$ thymidine incorporation) in patients who are anergic has been previously noted (31).

Another possible role for $\mathrm{T}$ lymphocytes is through collaboration with $\mathrm{B}$ lymphocytes in the production of specific IgE antibody. In this regard, Okumura and Tada (32) have shown that $\mathrm{T}$ lymphocytes are necessary to initiate an $\operatorname{IgE}$ response and may also function to regulate the amount of $\operatorname{IgE}$ antibody produced. Furthermore, Kishimoto and Ishizaka (33) have shown that the formation of $\operatorname{IgE}$ antibody requires carrier specific $\mathrm{T}$ helper cells. We found that lymphocyte activation (mediator production and lymphocyte transformation) in response to $\mathrm{RAgE}$ occurred in patients who had increased levels of specific IgEAR. This latter finding suggests the possibility that the lymphocyte response detected in our patients was that of the $T$ helper cell. It is possible that the $T$ helper cell response and that responsible for the expression of cutaneous delayed hypersensitivity are mediated by different lymphocytes, but their individual presence is not differentiated by our techniques.

In conclusion, it has been shown that elements of both 
immediate and delayed hypersensitivity are present in most untreated patients with ragweed hayfever. Of interest, a small number of patients did not exhibit a broad immunologic response to the major antigenic determinant in the ragweed extract (RAgE) but did manifest positive immediate skin. tests and lymphocyte transformation. This latter finding suggests that these patients may be sensitive to other antigens in the ragweed preparation or that their skin reaction to ragweed was not clinically significant. One might predict that in such patients a clinical response to ragweed immunotherapy would not be achieved, whereas those patients who exhibit a broad immunologic response to ragweed might receive some benefit from this type of therapy. If such patients are sensitive to another antigen which may cause their symptoms, it would be important to define this population in clinical trials.

\section{ACKNOWLEDGMENTS}

We wish to acknowledge the excellent technical assistance of Mr. Ruben Burnet and thank Doctors John R. David and Lawrence M. Lichtenstein for their helpful comments in the preparation of this manuscript.

This work was supported in part by a grant from the U. S. Army.

\section{REFERENCES}

1. Zeitz, J. S., P. P. VanArsdel, Jr., and D. K. McClure. 1966. Specific response of human lymphocytes to pollen antigen in tissue culture. J. Allergy. 38: 321.

2. Girard, J. P., N. R. Rose, M. L. Kunz, S. Kobayashi, and C. E. Arbesman. 1967. In vitro lymphocyte transformation in atopic patients: Induced by antigens. $J$. Allergy. 39: 65 .

3. Richter, M., and C. K. Naspitz. 1968. The in vitro blastogenic response of lymphocytes of ragweed-sensitive individuals. J. Allergy. 41: 140.

4. Brostoff, J., and I. M. Roitt. 1969. Cell-mediated (delayed) hypersensitivity in patients with summer hayfever. Lancet. 2 : 1269.

5. Maini, R. N., D. C. Dumonde, J. A. Faux, F. E. Hargreave, and J. Pepys. 1971. The production of lymphocyte mitogenic factor and migration inhibition factor by antigen-stimulated lymphocytes of subjects with grass pollen allergy. Clin. Exp. Immunol. 9: 449.

6. Massie, F. S., and R. Wutanasupta. 1972. Detection of delayed hypersensitivity in ragweed pollinosis by an in vitro method. Ann. Allergy. 30: 676.

7. Ling, N. R. 1968. Lymphocyte Stimulation. NorthHolland Publishing Co., Amsterdam.

8. David, J. R., and R. A. David. 1972. Cellular hypersensitivity and immunity. In Progress in Allergy. $P$. Kallos, B. H. Waksman, and A. De Weck, editors. S. Karger, Basel. 16: 302.

9. Wide, L., H. Bennich, and S. G. O. Johansson. 1967. Diagnosis of allergy by an in vitro test for allergen antibodies. Lancet. 2: 1105.

10. Yunginger, J. W., and G. J. Gleich. 1972. Comparison of the protein-binding capacities of cyanogen bromideactivated polysaccharides. J. Allergy Clin. Immunol. 50: 109 .
11. Greenwood, F. C., W. M. Hunter, and J. S. Glover. 1963. The preparation of ${ }^{131} \mathrm{I}$ labeled human growth hormone of high specific radioactivity. Biochem. J. 89: 114 .

12. Lichtenstein, L. M., and A. G. Osler. 1964. Studies on the mechanism of hypersensitivity phenomena. IX. Histamine release from human leukocytes by ragweed pollen antigen. J. Exp. Med. 120 : 507.

13. May, C. D., M. S. Lyman, R. Alberto, and J. Cheng. 1970. Procedures for immunochemical study of histamine release from leukocytes with small volume of blood. J. Allergy. 46: 12.

14. Shore, P. A., A. Burkhalter, and V. H. Cohn, Jr. 1959. A method for the fluorometric assay of histamine in tissues. J. Pharmacol. Exp. Ther. 127: 182.

15. Levy, D. A., L. M. Lichtenstein, E. O. Goldstein, and K. Ishizaka. 1971. Immunologic and cellular changes accompanying the therapy of pollen allergy. J. Clin. Invest. 50: 360 .

16. Thorsby, E., and A. Bratlie. 1970. A rapid method for preparation of pure lymphocyte suspensions. In Histocompatibility Testing. P. I. Terasaki, editor. Munksgaard, Copenhagen. 655.

17. Rocklin, R. E., G. Reardon, A. Sheffer, W. H. Churchill, and J. R. David. 1970. Dissociation between two in vitro correlates of delayed hypersensitivity: absence of migration inhibitory factor (MIF) in the presence of antigen-induced incorporation of ${ }^{8} \mathrm{H}$-thymidine. In Proceedings of the Fifth Leukocyte Culture Conference. Academic Press, Inc., New York. 639.

18. Rocklin, R. E., O. L. Meyers, and J. R. David. 1970. An in vitro assay for cellular hypersensitivity in man. J. Immunol. 104 : 95.

19. David, J. R., S. Al-Askari, H. S. Lawrence, and L. Thomas. 1964. Delayed hypersensitivity in vitro. I. The specificity of inhibition of cell migration by antigens. J. Immunol. 93 : 264.

20. Hill, A. B. 1961. Principles of Medical Statistics. The Lancet Ltd., London.

21. Lichtenstein, L. M., P. S. Norman, W. L. Winkenwerder, and A. G. Osler. 1966. In vitro studies of human rawweed allergy: changes in cellular and humoral activity associated with specific desensitization. J. Clin. Invest. 45: 1126.

22. Green, G. R., B. Zweiman, H. Beerman, and E. A. Hildreth. 1967. Delayed skin reactions to inhalant antigens. J. Allergy. 40: 224.

23. Go, S., D. L. Michaels, and E. F. Ellis. 1970. Delayed hypersensitivity to pollen. Lancet. 1: 1115.

24. Henderson, L. L., L. A. Swedlund, R. G. Van Dellen, J. P. Marcoux, H. M. Carryer, G. A. Peters, and G. J. Gleich. 1971. Evaluation of IgE tests in an allergy practice. J. Allergy Clin. Immunol. 48: 361.

25. Gleich, G. J., A. K. Averbeck, and H. A. Swedlund. 1971. Measurement of $\operatorname{IgE}$ in normal and allergic serum by radioimmunoassay. J. Lab. Clin. Med. 77: 690.

26. Spitz, E., E. W. Gelfand, A. L. Sheffer, and K. F. Austen. 1972. Serum IgE in clinical immunology and allergy. J. Allergy Clin. Immunol. 49: 337.

27. Lichtenstein, L. M., K. Ishizaka, P. S. Norman, A. K. Sobotka, and B. H. Hill. 1973. IgE antibody measurements in ragweed hay fever. Relationship to clinical severity and the results of immunotherapy. J. Clin. Invest. $52: 472$.

28. Amos, B. 1971. Progress in Immunology. Academic Press, Inc., New York.

29. Claman, H. N., E. A. Chaperon, and R. F. Triplett. 
1966. Thymus-marrow cell combinations. Synergism in antibody production. Proc. Soc. Exp. Biol. Med. 122: 1167.

30. Slavin, R. G., J. I. Tennenbaum, R. J. Becker, A. R. Feinberg, and S. M. Feinberg. 1963. Cell transfer of delayed hypersensitivity to ragweed from atopic subjects treated with emulsified ragweed extracts. $J$. $A l$ lergy. 34 : 368.

31. Churchill, W. H., R. E. Rocklin, W. C. Moloney, and J. R. David. 1973. Hodgkin's Disease: relationship of migration inhibitory factor (MIF) production and antigen-induced lymphocyte proliferation to delayed cutaneous hypersensitivity. Int. Symp. Hodgkin's Disease. Natl. Cancer Inst. Monogr. 36: 99.

32. Okumura, K., and T. Tada. 1971. Regulation of homocytotropic antibody formation in the rat. III. Effect of thymectomy and splenectomy. J. Immunol. 106: 1019.

33. Kishimoto, T., and K. Ishizaka. 1973. Regulation of antibody response in vitro. V. Effect of carrier-specific helper cells on generation of hapten-specific memory cells of different immunoglobulin classes. J. Immunol. 111: 1 . 